\title{
Technical efficiency of organic pasture farming in Germany: The role of location economics and of specific knowledge
}

\author{
S. Lakner ${ }^{\star}$, S. von Cramon-Taubadel and B. Brümmer \\ Department of Agricultural Economics and Rural Development, Georg-August University Göttingen, Platz der \\ Göttinger Sieben 5, D-37073 Göttingen, Germany. \\ ${ }^{*}$ Corresponding author: slakner@gwdg.de
}

\begin{abstract}
We analyze the efficiency of organic pasture farming in Germany using data from 1994/95 to 2005/06. Five inputs and one output are analyzed by means of a stochastic frontier production function, allowing for heteroscedasticity and technical effects. Five sets of possible determinants of technical efficiency are considered in the model. These include: (1) farm structure and resources; (2) human capital and management capacities; (3) institutional choice; and (4) subsidies. To these factors that are commonly included in technical effects models, we add (5) a set of variables that capture localization and urbanization economies such as the share of organic farms in a region and the regional share of votes for the Green Party in recent elections. These regional effects are found to have a significant impact on the technical efficiency of organic farms. The evolution of efficiency on farms that are converting from conventional to organic farming is also analyzed.
\end{abstract}

Key words: efficiency analysis, organic farming, location economics, specific knowledge

\section{Introduction}

The importance of organic farming has increased rapidly in the EU and especially Germany in recent years. The share of organic farmers in Germany grew from 1.3\% in 1996 to $5.9 \%$ in $2010^{1}$. Currently, 7.9 million hectares or $4.5 \%$ of the agricultural area in the EU is under organic production ${ }^{2}$. As concerns rise about agriculture's contribution to climate change, its influence on biodiversity, and issues such as animal welfare and food safety, EU and member state policy-makers can be expected to direct more attention and probably support toward organic farming.

Designing appropriate policies requires a solid understanding of the factors, such as technical efficiency (TE) that influence the competitiveness of organic farming. Due to the regulations that define and govern organic farming, organic production systems differ from conventional systems, and are subject to different relative scarcities. For example, since synthetic fertilizer use is not permitted in organic farming, nitrogen scarcity forces organic farmers to make efficient use of organic manure or nitrogen fixed, for example, by clover or other leguminous plants ${ }^{3}$. The greater dependence of organic production systems on the availability of natural resources could lead to a higher variance of TE scores in organic farming ${ }^{4}$.

The organic production regulation promotes more integrated farming systems. A study on organic dairy farms in the USA shows that on organic dairy farms the vertical integration produces substantial economies of scope (in contrast to conventional dairy farms). There seems to be a systematic incentive toward an integrated farming and against a high degree of specialization ${ }^{5}$, which is a special characteristic of organic farming systems too.

These issues warrant a closer look at efficiency in organic farming, and at the possible determinants of differences in efficiency between organic farms. Besides the standard determinants that are usually considered in efficiency analysis-such as farm structure or the age and educational status of the farm manager-we highlight two factors that have received little attention in the literature on the efficiency of organic farming to date.

The first of these factors is a farm's conversion status. Nieberg ${ }^{6}$ shows that grain yields fall to $53 \%$ of their starting level after 4 years on German farms that are converting from conventional to organic farming, and then recover slightly to $72 \%$ of the starting level by the sixth year. Farmers in conversion have to acquire specific 
knowledge and expertise for managing a new technology. Hence, one might expect TE to fall on a farm that has begun to convert, but to increase thereafter as the farmer acquires knowledge and expertise. This has implications for policy, if increasing the number of organic farms or the share of organic food production is a policy goal and policy-makers wish to design appropriate support packages for converting farms.

The second factor that has received little attention is location. In the past century, organic farming in Germany emerged in several distinct regional centers. The 'Demeter' movement influenced by Rudolf Steiner (1861-1925) started in the $1920 \mathrm{~s}$ on east German farms. In the 1960s and 1970s, many small farms in southern Germany and Switzerland followed the ideas of Hans Müller (1891-1988) and Hans-Peter Rusch (1906-1977). Finally, after German reunification, many farms in the former German Democratic Republic converted to organic farming with the support of EU agri-environmental schemes that were introduced with the 'MacSharry Reform' of $1992^{7}$. The emergence of organic farming in distinct geographic regions suggests that location effects such as localization and urbanization economies effects might have played a role in the development of the sector ${ }^{8}$ via their impact on farm-level efficiency.

In this paper, we analyze the determinants of the efficiency of organic pasture farms in Germany. Extending existing studies, we address two important questions for organic farming in Germany and elsewhere; whether location has a significant impact on TE and whether TE follows a distinct path over the course of the conversion period from conventional to organic farming. We proceed as follows: in the 'Background/Literature Survey' section, we provide a short overview of the recent literature on the impact of conversion and location effects on TE, and we propose a framework that includes location effects among the determinants of TE on organic pasture farms. In the 'Methods and Data' section, we present the methods and the data used in our empirical analysis. In the 'Results and discussion' section, we present and discuss the results, and the 'Conclusion' section concludes.

\section{Background/Literature Survey}

An extensive literature deals with the determinants of TE in farming in general ${ }^{4,9-14}$. This literature has identified the following four categories of determinants of TE:

1. farm structure and available natural resources;

2. management capacities and human capital;

3. institutional choice (legal form and tax options); and

4. market orientation and policy support.

Several studies investigate the TE of organic farms specifically ${ }^{4,15-20}$. The development of TE during the conversion period from conventional to organic farming is addressed in some of these studies. Lohr and Park ${ }^{19}$ studied the influence of the organic farm manager's experience in the USA by splitting the sample into farms with more than 5 years of experience in organic farming, and farms with less than 5 years. The authors found that efficiency grows with years of experience in organic production. According to Sipiläinen and Oude Lansink ${ }^{17}$, the learning process in organic dairy farms in conversion in Finland takes about 6-7 years following the decision to convert.

Initial studies of the location of organic farming in the 1980s and 1990s hypothesized that organic farms would cluster in the neighborhoods of cities with high population densities and therefore a high potential for direct marketing $^{21}$. After the introduction of per-hectare payments for organic farming by EU regulation 2078/92 in 1993, many farms converted in parts of east Germany where agroclimatic conditions are less favorable ${ }^{21}$. One determinant of the spatial distribution of organic farming might therefore be lower opportunity costs due to less profitable conditions for conventional farming.

Bichler et al. ${ }^{8}$ confirmed that there is a higher concentration of organic farms in German regions with less favorable soil quality. They also found a higher prevalence of organic farming in regions in which the difference between the subsidies provided for organic and for conventional pasture is large, and in regions in which greater shares of land have been designated as water protection or nature conservation areas. In some west German regions, local per capita income and farm size were also found to have a positive influence on the share of organic farms. Finally, Bichler et al. ${ }^{8}$ also provide evidence that the spatial distribution of organic farms tends to be more concentrated in proximity to big cities with high population densities. In Figure 1, we can see the local share of organic farms in the total number of farms at the county level in 2007, which in general shows the local concentration of organic farming, which is in the south, center-west and north-east of Germany.

A number of studies have analyzed the role of information spillovers on the spatial distribution of organic farming. Farmers in the UK who are converting from conventional to organic production receive most of their information from other organic farmers in the same region $^{24}$. Studies in Germany ${ }^{7}$ and Wales ${ }^{25,26}$ confirm that neighboring organic farmers are the main source of information for converting and converted organic farms. Regional networks of farmers and support groups encourage the regional concentration of organic farms in Wales and England $^{27}$. The importance of information exchange between farmers is probably greater for organic than for conventional farming, because until recently there were relatively few specialized extension and education/training services for organic farmers. This is generally true for the western European countries that we have studied, and certainly for Germany. Therefore, most knowledge and information had to be generated by organic farmers themselves and was disseminated via local working groups ${ }^{7}$. Where specialized extension services exist, they were found to have a positive impact on organic conversion rates ${ }^{28}$. 


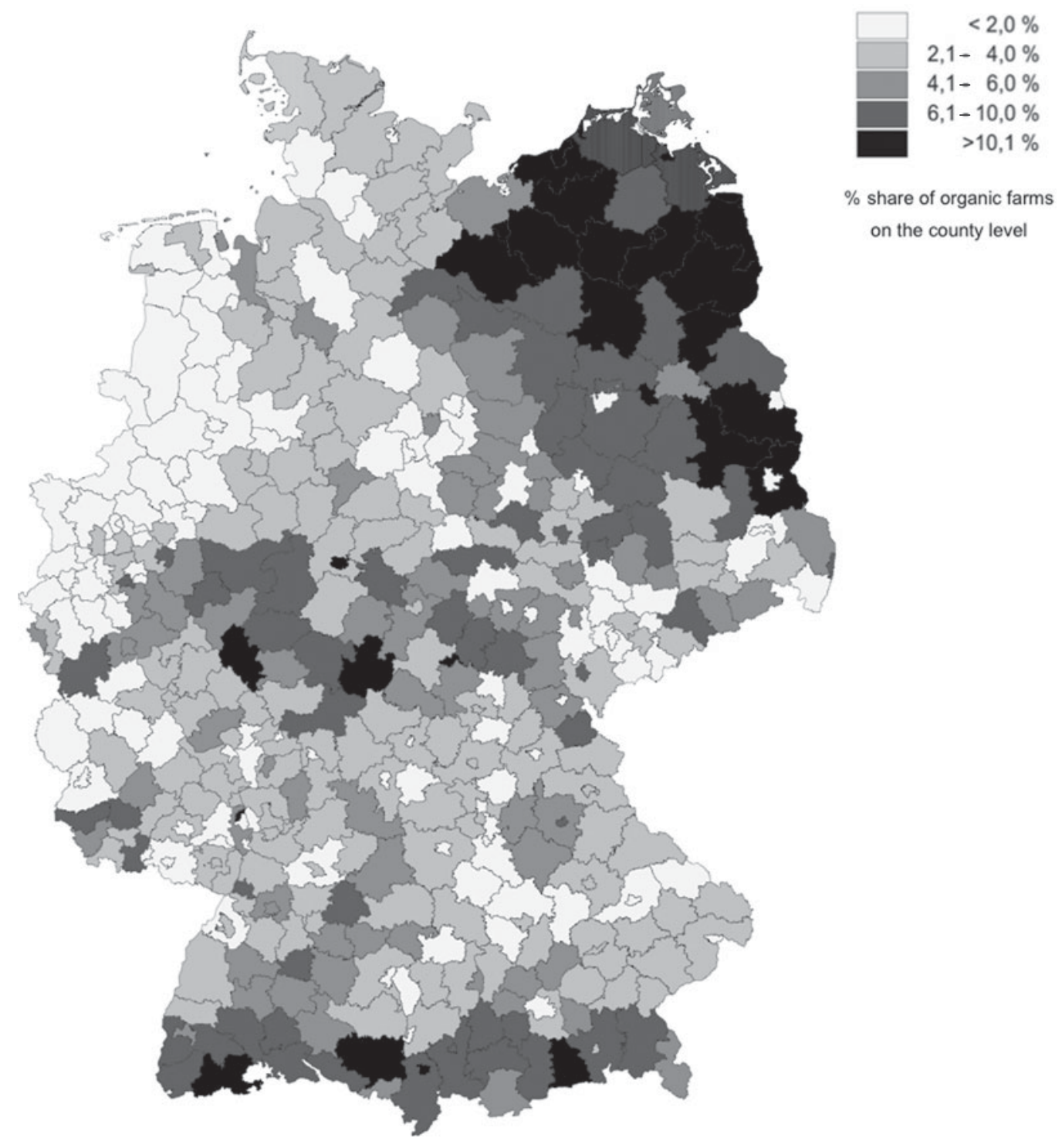

Figure 1. Regional concentration of organic farms in Germany in 2007. Source: Own calculation. Data on the county ('Landkreis') level from the German Federal Statistical Office ${ }^{22}$, Regional Database 2005 and $2007^{23}$. Due to administration reforms, in 15 of 457 counties there were no data in the regional statistics for the year 2007. For the missing data in 2007, we took data from the previous years 2005 or 2003 , assuming that the organic sector is constantly growing and we get a 'minimum number' of organic farms from $2003 / 2005$ for the year 2007.

If information spillovers between organic farms are important, it is reasonable to expect that location will have an impact on farm-level efficiency. While we are aware of no studies on the impact of location on the efficiency of organic farms, the impact of location on efficiency has been studied in other agricultural contexts. For example, according to one study, a high regional concentration of aquaculture farms in Norway is associated with lower output but higher efficiency ${ }^{29}$. In other studies, the total sales per employee increase with the number of organic processors and traders located in a county in the USA ${ }^{30}$, and regional concentration, distance to the nearest slaughterhouse, and the population density in neighboring regions influence the TE of pig farms in western France ${ }^{31}$. There is also evidence of spatial-efficiency clusters in
Ukrainian dairy farming, with proximity to other efficient farms and to dairy processors exercising a positive effect on efficiency and total factor productivity ${ }^{32}$.

Based on this review of the literature, we propose to consider - in addition to the four 'traditional' categories of factors that influence efficiency mentioned abovevariables that account for location effects. First, a large share of organic farmers in a region might create external advantages that are referred to as localization economies in location theory ${ }^{33}$. Localization economies arise when many firms from the same industry are located in a region. They include access to pooled markets for skilled labor, the regional emergence of firms that provide specific intermediate inputs, and ease of communication leading to technological spillovers. All of these factors are expected to 
have a positive impact on TE as the number of organic farmers in a region increases.

Second, the efficiency of organic farming might also benefit from urbanization economies ${ }^{34}$. Urbanization economies are the effects on a firm's economic performance that arise from regional economic activity in other sectors. At first glance, it may seem incongruous to discuss urbanization in connection with a distinctly rural activity such as organic farming. However, in a densely populated and comparatively decentralized country such as Germany, rural and urban areas lie close together and are strongly interlinked. It is reasonable to expect that organic farms will perform better in regions that are characterized by local communities that are sensitive to environmental concerns and willing to pay higher prices for organic products. Such regions will provide sufficient demand to sustain direct marketing, specialized retail outlets such as organic farmers' markets and restaurants that specialize in organic food, and processors such as organic bakers and dairy enterprises that benefit from a dependable local supply of organic farm products. Such regions will also be able to sustain special advisory services for organic farms, and service providers that cater to the needs and preferences of organic farmers (e.g., a Waldorf school for children, practitioners of alternative medicine). We capture urbanization effects with two variables. Since we study organic pasture farms, we use a farm's distance from the nearest organic dairy processor as an indicator of localdemand conditions. In addition, we use recent local election results of the Green Party as a measure of the overall local level of acceptance for organic farming. The Green Party in Germany has traditionally championed environmental issues and organic farming, and most organic farmers and their supporters come from a socio-economic background that is associated with support for the Green Party ${ }^{7}$.

\section{Methods and Data}

\section{Methods}

The field of empirical efficiency analysis in economics has grown very rapidly over the past roughly two decades, with applications not only in agriculture but also in many other areas such as health care provision and energy generation. Two main empirical approaches have been developed; so-called Data Envelopment Analysis (DEA) based on programming techniques and Stochastic Frontier Analysis (SFA) based on econometric estimation of production functions. We employ SFA in this paper. A brief explanation of this method follows; for a detailed exposition of SFA and DEA, see Coelli et al. ${ }^{35}$ and Kumbhakar and Lovell $^{36}$.

SFA estimates a producer's (in the following we will refer to farms) TE by measuring the distance between its observed input-output combination and the best-feasible input-output combination that it could obtain if it were located on the so-called 'production frontier'. This production frontier defines the highest possible amount of output that can be obtained from any given amount of input ('output oriented approach'). Alternatively, the frontier can be defined in terms of the lowest amount of input that is required to produce a given amount of output ('input oriented'). In agriculture, where many key inputs such as land, machinery and buildings are given, at least in the short run, the output-oriented approach is often favored.

Deviations between individual farms' observed output and the frontier output could occur for two reasons. The first reason is technical inefficiency-the fact that some farmers are more successful than others at putting the inputs at their disposal to the best possible use, i.e., at feeding cows to produce milk or at tending crops. The second reason is due to stochastic effects such as weather, luck or measurement errors. It is important to allow both components in order to avoid confounding the technical inefficiency estimates with purely random errors. The SFA approach accomodates this requirement by using a composed error structure, where one one-sided error component captures technical inefficiency, and a second error, symmetric error component, captures random deviations from the frontier. This basic SFA model is illustrated in Figure 2.

Due to the presence of stochastic effects, the production frontier is refered to as 'stochastic', and for Farms A and B with input levels $x_{a}$ and $x_{b}$ we see how its observed output deviates from its 'frontier output' $y_{b}{ }^{*}$ due to inefficiency and stochastic effects. Note that with a large positive stochastic effect $v$ the observed output can lie above the frontier. Econometric SFA techniques estimate the location of the stochastic production frontier from data on the input use and output production of a set of farms, and decompose the deviation of each individual farm's actual production from the frontier into its inefficiency and stochastic components. Of course, in reality, farms use many inputs to produce more than one output, but the SFA model depicted in Figure $2^{37,38}$ can be generalized to deal with the multiinput/multi-output case.

Formally, this generalized SFA model that we employ can be written as

$$
\begin{aligned}
& y_{i t}=f\left(x_{j i t} ; \beta\right)^{*} \exp \left\{w_{i t}\right\} \quad \text { with } w_{i t}=v_{i t}-u_{i t}, \\
& y_{i t}=f\left(x_{j i t} ; \beta\right) * \exp \left\{v_{i t}-u_{i t}\right\} .
\end{aligned}
$$

In these equations, $y_{i t}$ is the output of farm $i$ in year $t$ measured as its total agricultural revenue, and $x_{j i t}$ measures the use of input $j$ by farm $i$ in year $t$. In our application, there are $j=5$ inputs:

$x_{1}$ : intermediate inputs (such as feed and electricity);

$x_{2}$ : other operating expenses (such as repairs to buildings and machinery, insurance premia and fees for membership in professional organizations);

$x_{3}$ : the depreciation of fixed assets (buildings and machinery);

$x_{4}$ : labor, measured as total labor in agricultural working units per year; and 


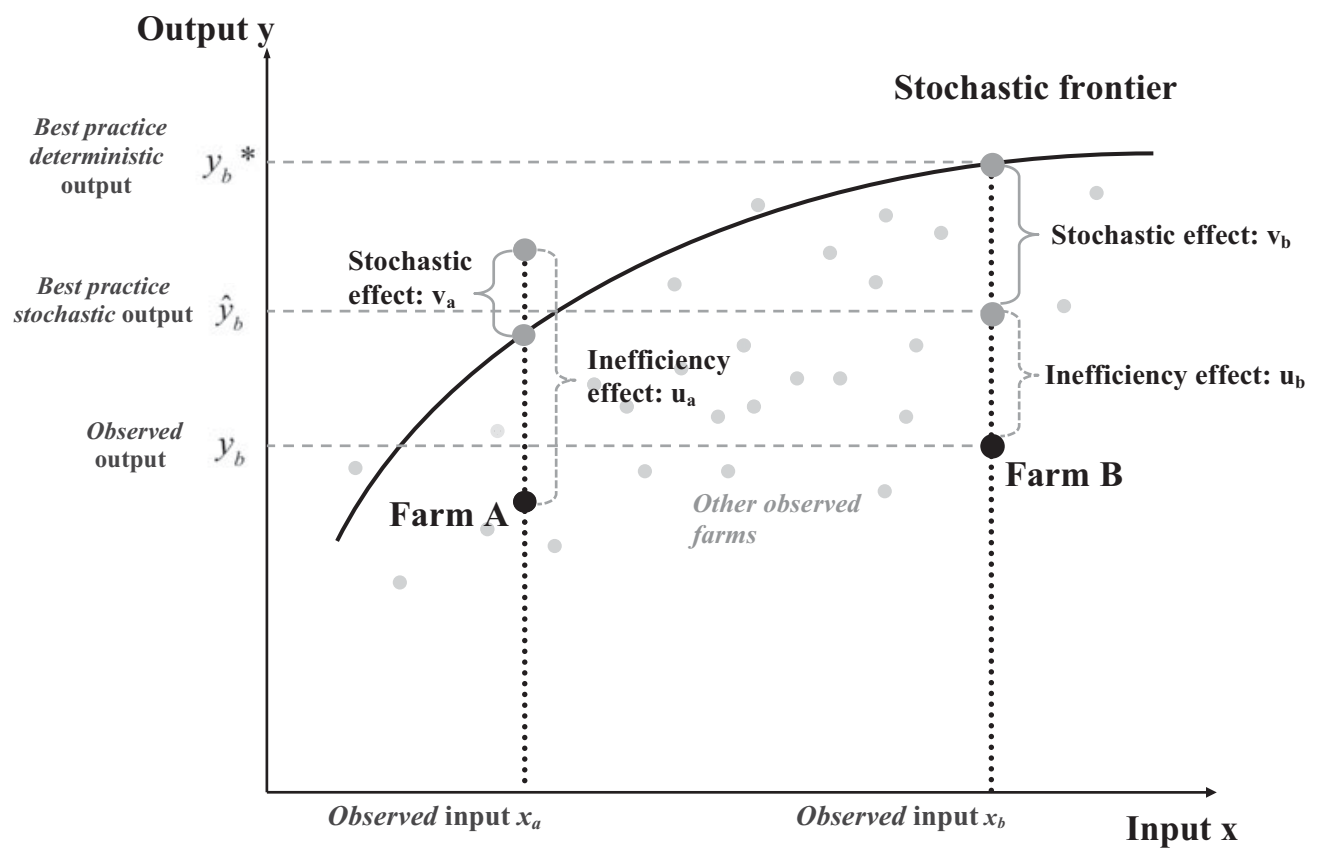

Figure 2. The estimation of the stochastic frontier model. Source: Own presentation based on Coelli et al. ${ }^{35}$ p. 244.

$x_{5}$ : land, measured as utilized agricultural area in hectares.

$\beta$ denotes a vector of parameters to be estimated that describe the specific mathematical form of the function $f(\cdot)$ that relates input use $x_{j i t}$ to output $y_{i t}$. In most applications of the SFA method, including ours, a functional form called the 'translog' is used. The translog function broadly satisfies the requirements of economic-production theory but is at the same time sufficiently flexible to allow the data to 'speak for themselves' and permit subsequent testing of conditions such as decreasing marginal returns to individual inputs and whether or not returns to scale in production are constant.

Finally, the combined error-term $w_{i t}$ in Equation 1 is split into the two components introduced above, as depicted in Equation 2. $v_{i t}$ captures stochastic effects for farm $i$ in year $t$ and is assumed to be normally distributed. $u_{i t}$ measures the inefficiency of farm $i$ in year $t ; u_{i t}$ is greater than or equal to zero because a farm's input-output combination can only lie below the production frontier (in which case $u_{i t}$ is positive and is a measure of the farm's inefficiency) or exactly on the frontier (in which case $u_{i t}$ equals zero and the farm is perfectly efficient). The nonnegative part of a normal distribution $u_{i t}$ is frequently used in SFA applications, and we follow this practice. Hence, denoting by $\mu$ the mean and by $\sigma_{u}{ }^{2}$ the variance of the underlying normal distribution, the inefficiency related errors $u_{i t}$ are modeled by truncation from below as $u_{i t} \sim N^{+}\left(\mu, \sigma_{u}{ }^{2}\right)$. The mean and the variance of the truncated distribution $u_{i t}$ itself will differ from $\mu$ and $\sigma_{u}{ }^{2}$, the mean is

$$
E(u)=\mu+\sigma \frac{\varphi(-\mu / \sigma)}{1-\Phi(-\mu / \sigma)},
$$

and the variance is

$$
\operatorname{VAR}(u)=\sigma^{2}\left(1-\frac{\varphi(-\mu / \sigma)}{1-\Phi(-\mu / \sigma)}\left(\frac{\varphi(-\mu / \sigma)}{1-\Phi(-\mu / \sigma)}\right)+\mu / \sigma\right)
$$

$\mathrm{TE}_{i t}$ is defined as the ratio of empirically observed output $\hat{y}_{i t}$ to the maximum feasible output $y_{i t}^{\max }=f\left(x_{j i t} ; \beta\right) \exp \left(v_{i t}\right)$ so that

$$
\mathrm{TE}_{i t}=\frac{\hat{y}_{i t}}{y_{i t}^{\max }}=\exp \left(-u_{i t}\right)
$$

Jondrow et al. $^{39}$ outline the econometric techniques that are used to decompose the error term $w_{i t}$ into its inefficiency and stochastic components $u_{i t}$ and $v_{i t}$, respectively ${ }^{39}$. Econometric estimation of the model in Equation 1 hinges on the assumption that both these error components are homoscedastic, in other words they have constant variances $^{36}$. However, this may not be the case. In particular, the inefficiency term $u_{i t}$ is likely to vary with the size of a farm, since a farm with a large input endowment (and therefore high output capacity) might exhibit substantially more variation, and therefore more scope for inefficiency than a smaller farm ${ }^{40}$. To account for this possibility, we estimate the following modification of the SFA model ${ }^{10,40}$.

$$
\sigma_{u_{i t}}=\exp \left(x_{j i t} \rho_{j}\right)
$$

In Equation 6, the variance of the inefficiency term is a function of the $j$ inputs $x_{i t}$ for farm $i$ in year $t$ introduced above, and $\rho_{j}$ is a corresponding set of $j$ parameters to be estimated. A positive estimate of $\rho_{j}$ implies that the corresponding input $x_{j}$ leads to a larger variance of the inefficiency term. This in turn indicates that the input has a negative impact on TE. 
Table 1. Description of the variables in the production function.

\begin{tabular}{llccccc}
\hline Variable description & & Unit & Minimum & Mean & Maximum & Standard deviation \\
\hline Sum of agricultural revenue & $y$ & $€$ & 586 & 91,752 & 931,220 & 72,162 \\
Intermediate inputs & $x_{1}$ & $€$ & 915 & 38,845 & 527,230 & 41,135 \\
Other operating expenses & $x_{2}$ & $€$ & 902 & 21,037 & 187,050 & 15,714 \\
Depreciation & $x_{3}$ & $€$ & 140 & 22,622 & 234,620 & 16,336 \\
Labor & $x_{4}$ & AWU/year & 0.13 & 1.81 & 15.16 & 1.09 \\
Land & $x_{5}$ & hectares & 0.70 & 65.75 & $1,041.80$ & 82.96 \\
\hline
\end{tabular}

Source: Own calculations.

I AWU, standardized agricultural work units.

The influence of additional potential determinants of TE can be estimated in terms of the parameter $\mu$ of the truncated normal distribution ${ }^{9}$ as specified in Equation 7:

$$
\mu_{i t}=z_{k i t} \delta_{k}+\mathrm{e}_{i t},
$$

where $z_{k i t}$ is a setof $k$ determinants of TE for farm $i$ in period $t$, and $\delta_{k}$ is a corresponding set of $k$ parameters to be estimated. A positive estimate of $\delta_{k}$ indicates that the corresponding variable $z_{k}$ increases the distance between a farm's input/output combination and the production frontier, and therefore has a negative impact on TE.

In order to see the regional distribution of efficiency scores, we applied a standard cluster analysis with the 'partitioning around medoids (PAM)' algorithm ${ }^{41}$. The idea is to cluster the farms according to their geographical location information, which are given as 'Universal Transverse Mercator (UTM)' values. We used the $x$ and $y$ values of the UTM value, which are the north-south- and the west-east-coordinates, as input to the algorithm to produce 15 regional cluster.

\section{Data}

We use accounting data for organic pasture farms in Germany from 1994/1995 to 2004/2005. Pasture farms are defined as 'specialized pasture farms' that derive more than $66 \%$ of their agricultural revenue from products based on pasture, or 'mixed farms with a focus on pature farming' that derive at least $33 \%$ of their revenue from such products. While some production of sheep, goats and suckler cows is pasture-based, the majority of the pasture in Germany is used in dairy production, and milk is the most important pasture-based output of the farms in our sample. The data were collected according to the agricultural accounting standard of the German Federal Ministry for Nutrition, Agriculture, and Consumer Protection, and made available by LAND DATA, which is a private firm that offers professional services with respect to bookkeeping and official tax declarations for farms. The dataset, therefore, covers farms that use the services provided by LAND DATA for their accounting, and hence is not the product of a representative sampling effort.

Since organic farming in Germany has been expanding rapidly over the past roughly 15 years, the characteristics of a representative sample have been changing as well. While the regional distribution of the farms in the sample is similar to that reported in official statistics ${ }^{42}$, two types of organic pasture farms are under represented. The first group comprises very small farms. Many of these farms have no detailed accounting, and most are part-time and can be considered non-commercial or hobby enterprises. These farms will presumably be of below-average efficiency (for example, because they have no accounting that could be used as a management tool), but their omission from the dataset is not critical because their share of pasture production in Germany is small, and they are not the farms that will shape the future of organic pasture farming in Germany. The other group of farms that is under represented are large former collective farms in eastern Germany that have converted to organic pasture production. Some of these farms are large enough to have their own accounting specialists and, hence, they do not engage the services of LAND DATA. Despite the fact that this type of farm is under represented, we do have a number of east German farms (62) in our sample, and there is no reason to expect any systematic differences between these farms and those that are not in the sample. Overall, we are confident that the sample provides a robust basis for analyzing the determinants of TE in German organic pasture farming, for a detailed discussion of the sample and its representativity, see Lakner ${ }^{42}$.

The subset of this data that we analyze consists of an unbalanced panel with 1717 observations from $i=396$ organic pasture farms over $t=11$ years. Observations with obvious inconsistencies or missing values were deleted from the sample, and monetary variables were deflated using the official price indices for agricultural products and for agricultural inputs that are provided annually by the German Federal Office for Statistics ${ }^{22}$. All input variables were normalized by dividing by sample means, except for the linear trend that enters in deviations from the sample mean.Table 1 describes the input and output variables in the production function.

We use the following set of $z$ variables as potential determinants of TE in the estimation of Equation 7 (variable names in italics, descriptive statistics in Table 2):

Management capacity and human capital. Farmers with No Agricultural Education from a university, technical college or agricultural school are expected to be less technically efficient. However, earlier studies find that 
Table 2. Variables used as determinants of TE.

\begin{tabular}{|c|c|c|c|c|c|}
\hline Variable & Unit & Minimum & Mean & Maximum & Standard deviation \\
\hline \multicolumn{6}{|l|}{ Management capacities and human capital } \\
\hline In conversion & $0 / 1$ & 0 & 0.1 & 1 & 0.3 \\
\hline No agricultural education of the farmer & $0 / 1$ & 0 & 0.1 & 1 & 0.3 \\
\hline Age of the farmer & Years & 20 & 43.5 & 70 & 8.4 \\
\hline Expenses for legal advice & $€$ & 0 & 58.3 & 6572 & 329.6 \\
\hline \multicolumn{6}{|c|}{ Farm structure and available natural resources } \\
\hline Soil quality & EMZ/ha & 25 & 3344.5 & 9877 & 1256.0 \\
\hline Equity share & $\%$ & 0 & 77.8 & 100 & 24.0 \\
\hline Sum of land rent & $€$ & 0 & 6428.4 & 111,290 & 9242.1 \\
\hline Volume of milk quota & $\mathrm{kg} / \mathrm{yr}$ & 0 & 8645.6 & 307,430 & $19,135.0$ \\
\hline Intensity of livestock production & $\mathrm{VE} / \mathrm{ha}^{\mathrm{l}}$ & 0 & 1.0 & 2.4 & 0.4 \\
\hline Pasture share & $\%$ & 0 & 61.2 & 100 & 28.1 \\
\hline \multicolumn{6}{|l|}{ Institutional choice (legal form, tax options) } \\
\hline $\begin{array}{l}\text { Legal status }=G b R \text { (civil law association } \\
\text { according to the German civil code) }\end{array}$ & $0 / 1$ & 0 & 0.2 & 1 & 0.4 \\
\hline Part-time farm & $0 / 1$ & 0 & 0.1 & 1 & 0.3 \\
\hline \multicolumn{6}{|l|}{ Market orientation and policy support } \\
\hline Volume of subsidies & $€$ & 0 & 12,588 & 163,990 & 10,659 \\
\hline \multicolumn{6}{|l|}{ Regional variables } \\
\hline Share of organic farmers & $\%$ & 0.3 & 4.2 & 16.4 & 2.8 \\
\hline Eastern Germany $^{2}$ & $0 / 1$ & 0 & 0.07 & 1 & 0.3 \\
\hline Northern Germany & $0 / 1$ & 0 & 0.05 & 1 & 0.2 \\
\hline Western Germany & $0 / 1$ & 0 & 0.08 & 1 & 0.3 \\
\hline Share of votes for the Green Party & $\%$ & 2.4 & 6.6 & 18.4 & 2.2 \\
\hline Distance to the nearest organic dairy & $\mathrm{km}$ & 4.9 & 38.4 & 154.4 & 26.3 \\
\hline
\end{tabular}

Source: Own calculations.

${ }_{1}^{1} \mathrm{VE}=$ 'Vieheinheiten', which are standardized animal units. ${ }^{2}$ The reference regional dummy variable is for southern Germany.

education has no impact on the success of organic farms ${ }^{18,43}$, and it may be that the education provided in most Germany universities, technical colleges and agricultural schools to date does not address the specific needs of organic farming. A farm manager's Age captures the impact of both education and experience. The literature includes studies with positive ${ }^{44}$ and negative ${ }^{10}$ impacts of age on TE. The impact of Expenses for Legal Advice is ambiguous: taking legal advice could lead to more efficient enterprise organization and management, but it might also reflect entanglement in disputes that bind resources and distract from other management tasks. As discussed above, farms in Conversion are expected to be less technically efficient.

Farm structure and resources. Soil Quality (EMZ/ha) is expected to exert a positive impact on $\mathrm{TE}^{18}$. Soil quality is measured in 'Ertragsmesszahl' (EMZ) according to the German soil classification system. EMZ/ha ranges from 25 (poorest) to 10,000 (best) and reflects characteristics such as soil texture (percentage of clay, silt and sand) and water retention capacity as well as climatic aspects such as temperature patterns. A high Share of Pasture Area in total agricultural area and a high Intensity of Livestock Production (measured in animal-units per hectare) are indicators of specialization that both can be expected to lead to higher efficiency. Financial management variables such as Share of Equity could affect TE in either direction ${ }^{13}$, depending on whether agency theory (monitoring) or credit-evaluation issues (lender aversion to risky credits) dominate. In the European Union, the milk production is limited by a milk quota that allows farmers to deliver milk to the dairies and that was originally distributed to the farms in 1984. Since 2004 quota can be traded within different German regions, which makes allocation of quota to growing farms possible, but which is also a cost factor. The Volume of Milk Quota owned by the farm might therefore have a positive impact on efficiency, since farms that own quota do not have to rent it. Furthermore, this variable captures the difference between milk producers and other pasture farms in the sample that do not produce milk (suckler cows, sheep and goats). Farmers who rent land are obliged to pay a market price for the use of this land, whereas those who farm their own land can hide a lack of efficiency behind lowimputed rental payments for this land. Hence, we expect that as a farm's Total Expenditure for Land Rental increases, so will its TE.

Institutional choices. Farms with the legal status of a Gesellschaft bürgerlichen Rechts (GbR or 'civil law association' according to the German Civil Law section 705) face high set-up costs and internal transaction costs. The $G b R$ is frequently observed when two or more farmers establish a partnerhsip. We therefore expect that the establishment of a $G b R$ will be associated with strategic 
Table 3. Coefficient estimates for the production function.

\begin{tabular}{lrrlrr}
\hline & Coefficient & $\boldsymbol{t}$-value & & Coefficient & $\boldsymbol{t}$-value \\
\hline$\beta_{0}$ & 0.3250 & 10.10 & $\beta_{14}$ & -0.0402 & -0.93 \\
$\beta_{1}$ & 0.3327 & 14.90 & $\beta_{15}$ & -0.0086 & -0.30 \\
$\beta_{2}$ & 0.1777 & 7.18 & $\beta_{1 \mathrm{t}}$ & 0.0008 & 0.17 \\
$\beta_{3}$ & 0.0798 & 4.25 & $\beta_{23}$ & 0.0705 & 1.94 \\
$\beta_{4}$ & 0.1832 & 6.15 & $\beta_{24}$ & -0.0339 & -0.78 \\
$\beta_{5}$ & 0.1772 & 5.46 & $\beta_{25}$ & 0.1158 & 3.10 \\
$\beta_{\mathrm{t}}$ & 0.0121 & 4.30 & $\beta_{2 \mathrm{t}}$ & -0.0005 & -0.11 \\
$\beta_{11}$ & 0.2179 & 8.40 & $\beta_{34}$ & -0.1459 & -4.48 \\
$\beta_{22}$ & 0.0004 & 0.01 & $\beta_{35}$ & -0.0149 & -0.40 \\
$\beta_{33}$ & 0.0666 & 1.70 & $\beta_{3 \mathrm{t}}$ & -0.0014 & -0.34 \\
$\beta_{44}$ & 0.0389 & 0.75 & $\beta_{45}$ & 0.0895 & 1.73 \\
$\beta_{55}$ & -0.0646 & -1.65 & $\beta_{4 \mathrm{t}}$ & 0.0040 & 0.69 \\
$\beta_{\mathrm{tt}}$ & -0.0067 & -4.20 & $\beta_{5 \mathrm{t}}$ & -0.0028 & -0.50 \\
$\beta_{12}$ & -0.1064 & -3.29 & $\ln \sigma_{\mathrm{v}}$ & -2.0170 & -36.90 \\
$\beta_{13}$ & -0.0504 & -1.31 & & & \\
\hline
\end{tabular}

Source: Own calculations.

restructuring efforts and, thus, increased TE. Part-Time Farms might be less efficient because a part of the family income is derived from other activities and the family therefore relies less on the efficiency of farm operations.

Market orientation/policy support. The impact of the Volume of Subsidies that a farm receives for organic production is ambiguous. Organic farms receive per hectare premium payments from EU agri-environmental programs (see EU-VO 2078/92 and EU-VO 1257/99). Many publications point to the negative impact that subsidies have on efficiency by weakening managerial efforts ${ }^{45,46}$. However, subsidies can lead to increased investment and thus efficiency, as for example reported in a study on dairy farms in Denmark, Sweden and Finland ${ }^{47}$. Hence, we formulate no expectations for this variable.

Location. The regional variables discussed above (Regional Share of Organic Farmers and Local Election Results of the Green Party) are provided by the German Federal Office for Statistics that provides data at the county level every 2 years ${ }^{23}$. Election results for the Green Party are taken from national elections. The results of state or local elections might better depict local voter preferences, but voter participation is much lower and more variable in these elections. The Distance to Nearest Organic Dairy was calculated using ArcView 10. We also include a set of dummy variables to capture regional differences in production systems in Germany. Analysis by the International Farm Comparison Network (IFCN) shows that the large milk producers that emerged from the former collective farms in eastern Germany are very competitive internationally ${ }^{48}$. Hence, we expect the dummy for eastern Germany (the omitted reference dummy is for southern Germany; dummies for northern and western Germany are also included) to have a significant positive impact on TE.

We estimated the model with Oxmetrics 6.0 and the program package sfamb for $o x^{49}$.

\section{Results and Discussion}

The estimation results for the production function model (Eqn 2) are presented in Table 3. Most of the estimated coefficients are significantly different from zero at the $5 \%$ level. Because all variables have been normalized by their respective sample mean prior to taking logarithms, the first-order estimates $\beta_{j}$ can be interpreted as partial production elasticities at the sample mean that shows how much the output would increase in percentage terms if the use of the respective input was increased by $1 \%$. Of the five inputs, intermediate inputs have the largest partial production elasticitiy $\left(\beta_{1}=0.33\right)$. The estimated elasticity of labor $\left(\beta_{4}=0.18\right)$ is larger than that found for conventional dairy farms ${ }^{10}$. This is plausible since the labor share is higher on organic than on conventional farms. The other inputs play less important roles. The estimated annual rate of technological progress (indicated by $\beta_{t}$ ) is $1.2 \%$.

The estimated ratio of the inefficiency variance to the total error variance, $\gamma=\sigma_{u}^{2} / \sigma_{u}^{2}+\sigma_{v}^{2}$, is 0.95 . Hence, most of the variation in the composite error term is due to the inefficiency component. The average TE score is 0.74 , with a standard deviation of 0.21 ; this indicates that the average farm in the sample is producing $74 \%$ of the maximum feasible output for its level of input use.

Table 4 presents the results of selected specification tests for the production function model with technical effects.

$H^{1}$ tests the hypothesis that every farm in the sample is fully efficient and that the introduction of an inefficiency term' is therefore not justified. This hypothesis is rejected, which indicates that inefficiency effects play a significant role. The hypothesis of linear homogeneity $\left(H^{2}\right)$ is rejected, which means that the assumption of globally constant returns to scale is not supported by the data. The mean scale elasticity is 0.93 and we find decreasing returns to scale on about $79.1 \%$ of the farms, meaning that if the use of all inputs was increased by some proportion $X$ on each of these farms, their output would increase by less than proportion $X$. This result contrasts with results for dairy farms in the USA, which show increasing returns to scale for both organic and conventional farms ${ }^{14}$. The rejection of $H^{3}$ indicates that the $z$ variables in Equation 7 have a significant joint impact on technical efficienty, and the rejection of $H^{4}$ indicates that the subset of $z$ variables that capture location effects also has a significant joint impact on TE. Other specification tests (available from the authors) favor the translog functional form of the frontier production function over the simpler Cobb-Douglas form. Overall, the results in Table 4 support the specification of the SFA model proposed above, including variables that capture location effects as determinants of TE.

The results from the 'heteroscedasticity model' (the parameter estimates for the $x$-variables presented in Eqn 6) show that efficiency is significantly affected by different factor endowments on the farms. For example, farms with higher levels of intermediate inputs, labor and land use 
Table 4. Results of tests for model quality.

\begin{tabular}{|c|c|c|c|c|}
\hline Test & Null hypothesis & Test value & Critical value $^{I}$ & Result \\
\hline$H^{1}$ : no inefficiency & $\gamma=0 ; \rho=0 ; \delta=0$ & $1,312.70$ & 30.81 & Reject \\
\hline$H^{2}$ : linear homogeneity & $\Sigma \beta_{\mathrm{j}}=1 ; \Sigma \Sigma \beta_{\mathrm{jk}}=0$ & 33.06 & 12.59 & Reject \\
\hline$H^{3}$ : no technical effects & $\delta_{0}=\delta_{1}=\ldots=\delta_{19}=0$ & 560.29 & 31.41 & Reject \\
\hline$H^{4}:$ no location effects & $\delta_{14}=\delta_{15}=\ldots=\delta_{19}=0$ & 53.13 & 12.59 & Reject \\
\hline
\end{tabular}

Source: Own calculations.

${ }^{I}$ Critical value for $H^{1}$ from Kodde and Palm ${ }^{50}$; the test statistics for $H^{2}$ through $H^{4}$ follow $\chi^{2}$ distributions. The critical values are significant at the $5 \%$ level of error probability; all test values are significant at the $1 \%$ level.

Table 5. Estimated coefficients for the technical effects model.

\begin{tabular}{|c|c|c|c|c|}
\hline Variable & Parameter & Coefficient & $t$-value & Marginal effect \\
\hline Constant & $\delta_{0}$ & -0.073 & -0.35 & \\
\hline In conversion & $\delta_{1}$ & $0.133 * * *$ & 2.58 & -0.004 \\
\hline No agricultural eduction of the farmer & $\delta_{2}$ & -0.069 & -0.72 & 0.002 \\
\hline Age of the farmer & $\delta_{3}$ & 0.0004 & 0.25 & -0.000 \\
\hline Expenses for legal advice & $\delta_{4}$ & $0.008 *$ & 1.82 & -0.0002 \\
\hline Soil quality & $\delta_{5}$ & $-0.100 * *$ & -2.52 & 0.003 \\
\hline Equity share & $\delta_{6}$ & -0.001 & -0.18 & 0.000 \\
\hline Sum of land rent & $\delta_{7}$ & $-0.031 * * *$ & -3.87 & 0.001 \\
\hline Volume of milk quota & $\delta_{8}$ & $-0.012 * * *$ & -2.87 & 0.0004 \\
\hline Intensity of livestock production & $\delta_{9}$ & $-0.441 * * *$ & -4.75 & 0.014 \\
\hline Pasture share & $\delta_{10}$ & $-0.068 * *$ & -2.10 & 0.002 \\
\hline Legal status $=G b R$ & $\delta_{11}$ & $-0.171 * *$ & -2.04 & 0.003 \\
\hline Part-time farm & $\delta_{12}$ & -0.085 & -1.26 & 0.002 \\
\hline Volume of subsidies & $\delta_{13}$ & $0.015 * *$ & 2.32 & -0.001 \\
\hline \multicolumn{5}{|l|}{ Regional variables } \\
\hline Regional share organic farmers & $\delta_{14}$ & $-0.130 * *$ & -1.98 & 0.004 \\
\hline Eastern Germany & $\delta_{15}$ & $0.221 * *$ & 2.27 & -0.004 \\
\hline Northern Germany & $\delta_{16}$ & $-0.363 * * *$ & -2.73 & 0.006 \\
\hline Western Germany & $\delta_{17}$ & $-0.346 * * *$ & -3.27 & 0.006 \\
\hline Share of votes for the Green Party & $\delta_{18}$ & $-0.099 *$ & -1.76 & 0.003 \\
\hline Distance to the nearest organic dairy & $\delta_{19}$ & $0.108 * *$ & 2.52 & -0.003 \\
\hline
\end{tabular}

Source: Own calculations.

*Estimated results with $10 \%$ error-probability, $* *$ estimated results with $5 \%$ error probability, $* * *$ estimated results with $1 \%$ error probability.

tend to have a smaller $\sigma_{u}$, in other words to be less inefficient.

Table 5 presents the parameter estimates and marginal effects for the determinants of TE (the $z$ variables in Eqn 7). Marginal effects measure the change in TE in percentage points due to a small change in the corresponding determinant ${ }^{51}$. These are estimated for the continuous variables by numerical differentiation at the sample mean, and for dummy variables, they measure the impact on TE of a unit change (from zero to one) in the corresponding variable.

Among the management variables, we find that farms in Conversion to organic production are less technically efficient than converted organic farms, a result that we discuss in more detail below. Farmers with No Agricultural Education are neither more nor less technically efficient than others, and Age also has no significant influence on efficiency. The first of these results confirms the results from other studies in organic farming ${ }^{14,18,43}$. It suggests that agricultural education in German universities, technical colleges and agricultural schools has, at least to date, not imparted knowledge and skills that contribute to technically efficient organic farming. Expenses for Legal Advice do not have a significant impact on TE.

As a farm's Soil Quality, Pasture Share and Volume of Milk Quota increase, so does its TE. A farm's Equity Share has no significant impact on its TE. As expected, the Total Expenditure for Land Rent has a positive impact on TE, and this impact is highly significant. Mayen et al. ${ }^{14}$ argue that renters of land might have lower incentives to use rented land efficiently. This might be true in the USA and in general for markets where rental prices of land are low. But as competition on the landmarket and rental prices for land increase (as in west Germany), the incentives to use land efficiently should increase as well, resulting in higherefficiency scores (as estimated here).

The Intensity of Livestock Production also has a strong influence on TE, with a $1 \%$ increase in intensity boosting efficiency by nearly $1.4 \%$. As expected, farms that have the 


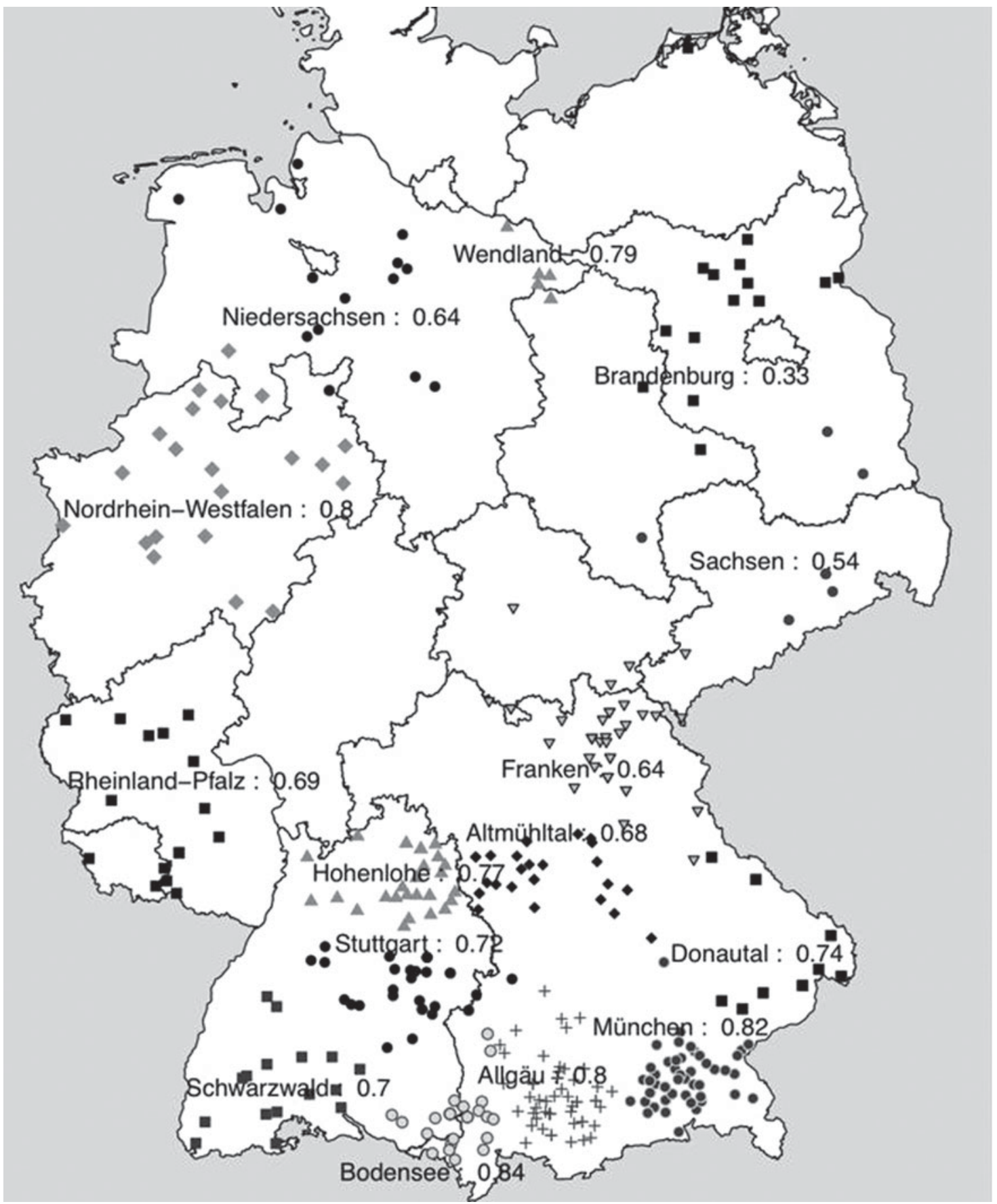

Figure 3. Average TE in 15 clusters of organic pasture farms in Germany. Source: Own presentation.

status of a $G b R$ perform better than those that have adopted other legal forms. Part-Time Farms are more efficient, but this effect is not statistically significant. Farms that receive larger Volumes of Subsidies have lower-efficiency scores, although the impact is small. This may be evidence that subsidies for organic farms, which largely take the form of payments for agri-environmental services, lead farms to pursue other activities that detract from the core pursuit of efficient pasture-based production.

Most of the coefficients for variables that capture location effects are significant at the 5\% level. There are distinct regional differences in TE. Compared with the reference region (southern Germany), the pasture farms in western and northern Germany are more efficient, other things being equal, while the pasture farms in eastern Germany are less efficient. This contradicts the findings of other studies ${ }^{48}$, which find that organic milk producers are more competitive in eastern Germany than in other regions. However, the magnitude of the differences estimated here is small; farms in eastern Germany are on average $0.4 \%$ less efficient than those in southern Germany, and $1.0 \%$ less efficient than those in northern and western Germany. Furthermore, TE is only one component of competitiveness $^{52}$; it could be that organic pasture farms 
Technical efficiency scores for farmers in the first 11 years after conversion

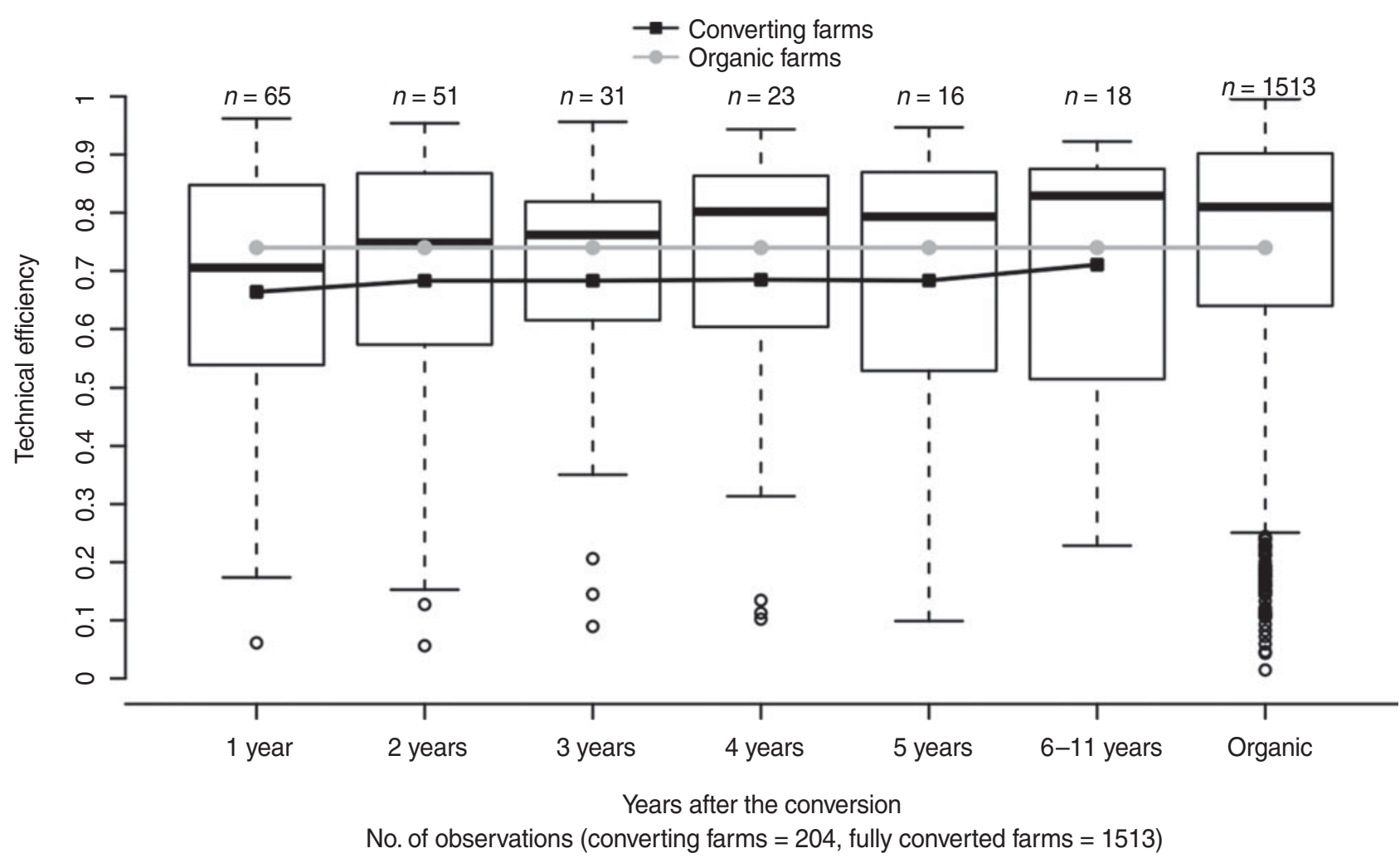

Figure 4. TE scores for farmers in the first 11 years after conversion. Source: Own calculations. Note that in the figure the efficiency of the farms 'in conversion' ( $n=204$, in black) is grouped according to the year after their conversion (i.e., 1 year, 2 years, ...), whereas the performance of fully converted organic farms $(n=1513$, in grey) is grouped altogether, denoted as 'organic'. The boxplots $1-6$ are based on the data of the farms in the 11 years after the conversion (i.e., $n=204$ ), boxplot 7 depicts the distribution of the fully converted organic farms (i.e., $n=1513$ ).

in eastern Germany are able to compensate for their slightly lower TE by being larger and thus being able to negotiate better prices for their input purchases and output sales.

The significant negative coefficient on the variable Regional Share of Organic Farmers is evidence in favor of localization economies in organic pasture farming. The fact that TE decreases with increasing Distance to the Nearest Organic Dairy and increases with the Share of Votes for the Green Party suggests that urbanization economies also play a role. All other things being equal, a $1 \mathrm{~km}$ reduction in the distance to the nearest organic dairy is accompanied by a $0.3 \%$ increase in TE, while a $1 \%$ increase in the local Green election result increases TE by $0.3 \%$.

Regional cluster (modeled as described in subsection 'Data') reveals that TE varies substantially across regions. Figure 3 shows 15 regional clusters with their mean TE score.

Especially in southern Germany we can find very efficient clusters ('Allgäu' with 0.8 , Bodensee with 0.84 and the region of Munich with 0.82 average TE), whereas the clusters in east Germany show a relatively low performance (Saxony with 0.54 and Brandenburg with 0.33 average TE). Interestingly, especially the southern region with a very high share of organic farms in the south perform very well, whereas in the north-eastern regions, where we can also find high shares of organic farms (see Fig. 1), the efficiency performance is low.

Returning to the impact of conversion from conventional to organic farming, Figure 4 illustrates the development of TE over the course of conversion to organic farming. Figure 4 shows that converting farms have lower levels of average TE than converted farms, but that this gap closes over time. These results are as expected and coincide with the findings of Lohr and Park ${ }^{19}$, who find lower TE scores in converting farms with less than 5 years of experience. Note that lower efficiency during conversion might be partly price-driven because the output of farms in conversion does not qualify as 'fully' organic, i.e., it has to be labeled differently and generally sells for lower prices. In a sample of organic farmers in Austria that had converted back to conventional production after 5 years, $58 \%$ reported converting back because they had only received conventional prices for their organic output ${ }^{53}$. Since we measure output in monetary terms in our application, lower prices could be showing up as reduced efficiency. However, closer examination of the data reveals no significant price differences between the converting and converted farms 
in our sample, which suggests that the lower TE of converting farms is not price driven.

The boxplots 1-6 in Figure 4 provide information on the distribution of efficiency scores for farms in the first 11 years after the conversion $(n=204)$, boxplot 7 shows the respective distribution for organic farms that are already converted $(n=1513)$. They show that in most years the distribution of TE is wider in the group of the converting farms than in the reference group of converted organic farms. They show that although converting farms are less technically efficient on average, the range of efficiencies is large and highly skewed toward lower-efficiency scores. The same is true of the efficiency distributions for converted farms.

\section{Conclusions}

We studied the TE of organic pasture farms in Germany using an unbalanced panel with 1717 observation from 396 farms over 11 years. TE is estimated using a stochastic translog production frontier that allows for the simultaneous estimation of the impact of specific variables on technical inefficiency. Along with the factors such as a farmer's age and education that are commonly used to explain TE in agriculture, we explicitly include variables that capture localization and urbanization effects.

The empirical results confirm that localization and urbanization effects do influence the TE of organic pasture farms in Germany. Specifically, TE increases with the regional share of organic farmers, with decreasing distance to the nearest organic milk processing plant, and with the regional share of votes for the 'Green Party' in federal elections. This suggests that future studies of TE in organic agriculture and also agriculture in general should take localization and urbanization effects into account or risk mis-specification. Our results also confirm that the conversion status of an organic farm can have a significant impact on its efficiency. As long as organic farming expands, samples of organic farms will include farms at different stages of the conversion process, and the results here suggest that empirical analysis should explicitly account for this.

The results of our analysis also have implications for policy. We find that organic farmers who have received no specific agricultural education are not less efficient than other organic farmers. While our binary measure of specific agricultural education is admittedly simple, this result matches the results of other studies and supports the supposition of many proponents of organic farming in Germany that agricultural education to date in Germany (which is almost exclusively publicly funded) has not been tailored to the needs of organic farming.

We also find that TE falls significantly with the volume of subsidies received, which was not expected ex ante. This might be evidence that the agri-environmental activites for which organic pasture farmers receive special subsidies are detracting from the efficient management of their core production activities. Of course, if farmers are volunteering to participate in these schemes, then presumably the subsidies that they are receiving in return must compensate for any resulting loss in efficiency. Nevertheless, if this explanation holds, German policy-makers might want to reconsider the types of subsidies that they have been providing to organic farming and design schemes that increase rather than decrease efficiency. However, this result might also reflect that the less efficient farmers are more likely to opt for participation in subsidy programs. Note that some of these programs require delivery of concrete environmental benefits, which from a broader perspective might compensate for lower TE. This links to the topic of 'environmental efficiency',54, where more research seems to be necessary.

Finally, we find that farms that are converting to organic production are less efficient on average than converted farms, although the difference in efficiency between these groups of farms falls as conversion progresses. This finding could be used to justify temporary and phased support for converting farms ${ }^{55}$. In most German federal states, the special premia for farms converting to organic production were abolished in 2006/2007. However, our results also show that the distribution of TE among converting organic pasture farms is wide and skewed. Therefore, it would be difficult to determine an appropriate level of support and in particular avoid overcompensation of converting farms that are relatively efficient. How to dose and target support and what instruments should be used to provide it (e.g., per hectare payments, price supports and extension) are topics for further research.

\section{References}

1 Organic Food Industry Federation 2011. Zahlen, Daten, Fakten: Die Bio-Branche 2011. Document yearly updated by the Organic Food Industry Federation (Bund Ökologische Lebensmittelwirtschaft (BÖLW)), Berlin, Germany. Available at Web site: http://www.boelw.de/zdf.html (accessed March 15, 2011).

2 Research Institute of Organic Agriculture 2010. Development of organic agricultural land, share of total agricultural land, organic operators in Europe 2003-2009. Database continually updated by the Research Institute of Organic Agriculture (FiBL), Frick, Switzerland. Available at Web site: http://www. organic-europe.net (accessed July 5, 2010).

$3 \mathrm{He}$, J. 1997. Systemimmanenter Zwang zu möglichst geschlossenen Nährstoffkreisläufen. Ökologie und Landbau 103:10-13.

4 Kumbhakar, S.C., Tsionas, E.G., and Sipiläinen, T. 2009. Joint estimation of technology choice and technical efficiency: an application to organic and conventional dairy farming. Journal of Productivity Analysis 31:151-161.

5 Mayen, C.D., Balagtas, J.V., and Alexander, C.E. 2009. Vertical economies of scope in dairy farming. Journal of Agricultural and Food Industry Organization 7(1). Available at: http://www.bepress.com/jafio/vol7/iss1/art8 (accessed March 14, 2011). 
6 Nieberg, H. 2001. Umstellung auf ökologischen Landbau: Wer profitiert? Ökologie und Landbau 118:6-9.

7 Gerber, A., Hoffmann, V., and Klügler, M. 1996. Das Wissenssystem im ökologischen Landbau in Deutschland - zur Entstehung und Weitergabe von Wissen im Diffusionsprozess. Berichte über Landwirtschaft 74:591-627.

8 Bichler, B., Lippert, C., Häring, A., and Dabbert, S. 2005. Die Bestimmungsgründe der räumlichen Verteilung des ökologischen Landbaus in Deutschland. Berichte über Landwirtschaft 83:50-75.

9 Battese, G.E. and Coelli, T.J. 1995. A model for technical inefficiency effects in a stochastic frontier production function for panel data. Empirical Economics 20:325-332.

10 Brümmer, B. and Loy, J.-P. 2000. The technical efficiency impact of farm credit programmes: a case study of northern Germany. Journal of Agricultural Economics 53:405-418.

11 Balmann, A. and Czasch, B. 2001. Zur Effizienz landwirtschaftlicher Unternehmen in Brandenburg-Eine Data Envelopment Analysis. Agrarwirtschaft 50:198-203.

12 Curtiss, J. 2002. Efficiency and Structural Changes in Transition-A Stochastic Frontier Analysis of Czech Crop Production. Shaker Verlag, Aachen, Germany.

13 Davidova, S. and Latruffe, L. 2007. Relationships between technical efficiency and financial management for Czech Republic farms. Journal of Agricultural Economics 58: 269-288.

14 Mayen, C.D., Balagtas, J.V., and Alexander, C.E. 2010. Technology adoption and technical efficiency: organic and conventional dairy farms in the United States. American Journal of Agricultural Economics 92(1):181-195.

15 Oude Lansink, A., Pietola, K., and Bäckman, S. 2002. Efficiency and productivity of conventional and organic farms in Finland 1994-1997. European Review of Agricultural Economics 29:51-65.

16 Tzouvelekas, V., Pantzios, C.J., and Fotopoulos, C. 2001. Technical efficiency of alternative farming systems: the case of Greek organic and conventional olive-growing farms. Food Policy 26:549-569.

17 Sipiläinen, T. and Oude Lansink, A. 2005. Learning in organic farming - an application on Finnish dairy farms. Contributed paper to the XI. EAAE Congress 'The Future of Rural Europe in the Global Agri-Food System' 2005, Copenhagen, Denmark. p. 1-22. Available at Web site: http://purl.umn. edu/24493 (accessed June 7, 2011).

18 Gubi, G. 2006. Analyse der erfolgs- und effizienzbestimmenden Faktoren im ökologischen Landbaus. PhD thesis, Institute for Agricultural Economics, Christian-Albrechts Universität, Kiel, Germany. Available at Web site: http://eldiss.uni-kiel.de/ macau/receive/dissertation_diss_00001845 (accessed June 7, 2011).

19 Lohr, L. and Park, T. 2006. Technical effects of U.S. organic farmers: the complementary roles of soil management techniques and farm experience. Agricultural and Resource Economics Review 35:327-338.

20 Francksen, T., Gubi, G., and Latacz-Lohmann, U. 2007. Empirische Untersuchungen zum optimalen Spezialisierungsgrad ökologisch wirtschaftender Marktfruchtbetriebe. Agrarwirtschaft 56:187-200.

21 Schulze Pals, L. 1994. Ökonomische Analyse der Umstellung auf ökologischen Landbau. Schriftenreihe des Bundesministierum für Ernährung, Landwirtschaft und Forsten, Series A, Vol. 436. Landwirtschaftsverlag, Münster, Germany.
22 Destatis 2006. Statistical Yearbook Agriculture 2006. Federal Statistical Office Germany (Destatis), Wiesbaden, Germany.

23 Destatis 2007. Regional database Germany-Online database. Federal Statistical Office Germany (Destatis), Wiesbaden, Germany.

24 Burton, M., Rigby, D., and Young, T. 1999. Analysis of the determinants of adoption of organic horticultural techniques in the UK. Journal of Agricultural Economics 50:47-63.

25 Padel, S. 2001a. Conversion to organic farming: a typical example of the diffusion of innovation? Sociologia Ruralis 41:40-61.

26 Padel, S. 2001b. Conversion to organic milk production: the change process and farmers' information needs. $\mathrm{PhD}$ thesis, Institute of Rural Studies, University of Wales, Aberystwyth, Wales.

27 Ilbery, B., Holloway, L., and Arber, R. 1999. The geography of organic farming in England and Wales in the 1990s. Tijdschrift voor Economische en Sociale Geografie 90: 285-295.

28 Frederiksen, P. and Langer, V. 2004. Localization and concentration of organic farming in the 1990s - the Danish Case. Tijdschrift voor Economische en Sociale Geografie 95(5):539-549.

29 Tveteras, R. and Battese, G.E. 2006. Agglomeration externalities, productivity and technical efficiency. Journal of Regional Science 46:605-625.

30 Jaenicke, E.C., Goetz, S.J., Wu, P.C., and Dimitri, C. 2009. Identifying and measuring the effect of firm clusters among certified organic processors and handlers. Contributed paper at the Annual Meeting of Agricultural and Applied Economics Association 2009, AAEA, Milwaukee, Wisconsin, USA. Available at Web site: http://purl.umn.edu/49205 (accessed March 15, 2011).

31 Larue, S. and Latruffe, L. 2008. Agglomeration externalities and technical efficiency in pig production. Contributed paper at the 12th Congress of the European Association of Agricultural Economists - EAAE 2008, Ghent, Belgium. Available at Web site: http://purl.umn.edu/44272 (accessed June 7, 2011).

32 Nivievskiy, O. 2009. Price support, efficiency and technology change of Ukrainian dairy farms: Spatial dependence in the components of productivity growth. Contributed paper at the IAAE 2009 Conference, Beijing, China. Available at Web site: http://purl.umn.edu/51403 (accessed June 7, 2011).

33 Krugman, P. 1991. Geography and Trade. MIT Press, Cambridge, USA.

34 Maier, G. and Tödtling, F. 1995. Regional und Stadtökonomik-Standorttheorie und Raumstruktur, 2nd ed. Springer, Berlin, Germany.

35 Coelli, T.J., Rao, D.S., Prasada, O’Donnell, C.J., and Battese, G.E. 2005. An Introduction to Efficiency and Productivity Analysis, 2nd ed. Springer, New York, USA.

36 Kumbhakar, S. and Lovell, K.C.A. 2000. Stochastic Frontier Analysis. University Press, Cambridge, USA.

37 Aigner, D., Lovell, K.C.A., and Schmidt, P. 1977. Formulation and estimation of stochastic frontier production function models. Journal of Econometrics 6:21-37.

38 Meeusen, W. and van den Broek, J. 1977. Efficiency estimation from Cobb-Douglas production functions with composed error. International Economic Review 18:435-444.

39 Jondrow, J., Lovell, K.C.A., Materov, I.S., and Schmidt, P. 1982. On the estimation of technical inefficiency in the 
stochastic frontier production function model. Journal of Econometrics 19:233-238.

40 Caudill, S.B., Ford, J.M., and Gropper, D.M. 1995. Frontier estimation and firm specific inefficiency measures in the presence of heteroscedasticity. Journal of Business and Economic Statistics 13:105-111.

41 Kaufman, L. and Rousseeuw, P.J. 1990. Finding Groups in Data-An Introduction into Cluster Analysis. Wiley Interscience, Hoboken, NJ, USA.

42 Lakner, S. 2010. Effizienzanalyse im ökologischen Landbau Bestandsaufnahme, empirische Analyse und agrarpolitische Schlussfolgerungen. PhD thesis, Department for Agricultural Economics and Rural Development, Georg-AugustUniversity, Göttingen, Germany. Available at Web site: http://webdoc.sub.gwdg.de/diss/2010/lakner/ (accessed July $15,2010)$.

43 Offermann, F. and Nieberg, H. 2001. Wirtschaftliche Situation ökologischer Betriebe in ausgewählten Ländern Europas: Stand, Entwicklung und wichtige Einflussfaktoren. Agrarwirtschaft 50:421-427.

44 Karagiannias, G., Salhofer, K., and Sinabell, F. 2006. Technical efficiency of conventional and organic farms: some evidence for milk production. Contributed paper at the 16 Conference of the Austrian Society of Agricultural Economics 'Ländliche Betriebe und Agrarökonomie auf neuen Pfaden'. Wien, Austria.

45 Leibenstein, H. 1966. Allocative efficiency vs. X-efficiency. American Economic Review 56:392-415.

46 Giannakas, K., Schones, R., and Tzouvelekas, V. 2001. Technical efficiency, technological change and output growth of wheat farms in Saskatchewan. Canadian Journal of Agricultural Economics 49:135-152.

47 McCloud, N. and Kumbhakar, S.C. 2007. Does subsidy drive productivity? A cross-country analysis of Nordic Dairy Farms. In S. Chib, G. Koop, and B. Griffiths (eds). Advances in Econometrics: Bayesian Econometrics. Emerald Books, Bingley, England.
48 Hemme, T., Deeken, E., and Faßbender, W. 2004. Internationale Wettbewerbsfähigkeit der ökologischen Milchproduktion und Verarbeitung in Deutschland, Report No 02OE059 at the von Thünen Institute, Institute for farm economics, Braunschweig, Germany. Available at Web site: http://orgprints.org/10743/ (accessed June 7, 2011).

49 Brümmer, B. 2001. Stochastic Frontier Analysis using SFAMB for Ox, Manual at the Institute for Agricultural Economics, Christian-Albrechts-University, Kiel, Germany.

50 Kodde, D.A. and Palm, F.C. 1986. Wald criteria for jointly testing equality and inequality restrictions. Econometrica 54:1243-1248.

51 Wilson, P., Hadley, D., and Asby, C. 2001. The influence of management characteristics on the technical efficiency of wheat farmers in Eastern England. Agricultural Economics 24:329-338.

52 Nivievskiy, O., Brümmer, B., and von Cramon-Taubadel, S. 2010. A Note on Technical Efficiency, Productivity Growth and Competitiveness. Contributed paper at the Joint Annual Meeting of the Agricultural \& Applied Economics Association (AAEA), Denver, Colorado, USA. Available at Web site: http://purl.umn.edu/61759 (accessed March 10, 2011).

53 Darnhofer, I., Eder, M., Schmid, J., and Schneeberger, W. 2005. Ausstieg aus der ÖPUL- Maßnahme biologische Wirtschaftsweise. In J. Heß and G. Rahman (eds). Proceedings of the 8th Scientific Conference for Organic Farming 'Ende der Nische'. Verlag Dr. Köster, Berlin. p. 467-470.

54 Kantelhardt, J., Eckstein, K., and Hoffmann, H. 2009. Assessing programmes for the provision of agri-environmental services - An efficiency analysis realized in Southern Germany. Contributed paper at the IAAE 2009 Conference, Beijing, China. Available at Web site: http://purl.umn.edu/ 51688 (accessed June 8, 2011).

55 Lohr, L. and Salomonsson, L. 2000. Conversion subsidies for organic production: results from Sweden and lessons for the United States. Agricultural Economics 22:133-146. 